(c) American Dairy Science Association, 2003.

\title{
Streptococcus thermophilus 580 Produces a Bacteriocin Potentially Suitable for Inhibition of Clostridium tyrobutyricum in Hard Cheese
}

\author{
A. G. Mathot, ${ }^{\star}$ E. Beliard, ${ }^{\star}$ and D. Thuault $\dagger$ \\ *Laboratoire Universitaire de Microbiologie Appliquée de Quimper, IUT de Quimper, \\ 2, rue de l'Université, Quimper, F29334 \\ $\dagger$ Association pour le Développement de la Recherche en Industrie Alimentaire, \\ Quimper, F29000
}

\begin{abstract}
A strain of Streptococcus thermophilus that inhibits Clostridium tyrobutyricum has been isolated from raw milk. The active compound produced disappears after a treatment with protease. However, unlike most bacteriocins, it is not thermoresistant, and the activity is completely lost after $1 \mathrm{~h}$ at $60^{\circ} \mathrm{C}$. Its inhibitory spectrum is limited to other thermophilic streptococci, Brochothrix, and sporulated gram-positive rods. So this bacteriocin could be different from those already described.

This bacteriocin-producing strain could be used in thermophilic starter for hard cheese making because the bacteriocin is not active against thermophilic lactobacilli. It is produced in M17 medium during the decreasing temperature phase of the hard cheese-making process temperature cycle and is also produced in milk. Moreover, when Streptococcus thermophilus was cocultured with a Lactobacillus delbrueckii subsp. lactis starter strain, it seems to enhance the bacteriocin production. However the level of activity always decreases drastically during the stationary phase. But inhibition of Clostridium tyrobutyricum spores can be obtained in small-scale curds.
\end{abstract}

(Key words: bacteriocin, coculture, Streptococcus thermophilus, Clostridium tyrobutyricum inhibition)

Abbreviation key: AU = arbitrary unit, $\mathbf{N C F S}=$ neutralized cell free supernatant, $\mathbf{R S M}=$ reconstituted skim milk.

\section{INTRODUCTION}

Bacteriocins produced by lactic acid bacteria have been the subject of much research work in recent years because of their potential use as novel, natural food

Received January 2, 2001

Accepted July 8, 2002.

Corresponding author: A. G. Mathot; e-mail: mathot@iutquimp. univ-brest.fr. preservatives; medical purposes have also been considered (Abee et al., 1995; Ross et al., 1999).

Bacteriocin-producing strains of Streptococcus thermophilus have been reported but, to our knowledge, only five bacteriocins have been more or less characterized: thermophilin 347 produced by a strain isolated from yogurt (Villani et al., 1995), thermophilin A (Ward and Somkuti, 1995), thermophilin $\mathrm{T}$ produced by a strain isolated from "feta" cheese (Aktypis et al., 1998), thermophilin 13, which has been sequenced (Marciset et al., 1997) and a bacteriocin from $S$. thermophilus 81 with a broad inhibitory spectrum (also active against gram-negative bacteria) (Ivanova et al., 1998).

Streptococcus thermophilus, Lactobacillus helveticus, and Lactobacillus delbrueckii subsp. lactis are the main species present in thermophilic cheese starters, so these bacteria potentially could be used to inhibit Clostridium tyrobutyricum. This sporulating bacteria contaminates milk via silage and provides a late swelling during ripening of Emmental-type cheese. Several methods have been proposed to prevent this spoilage, but none is totally satisfactory. Few bacteriocins have been proposed: Nisin is less effective against Clostridium spp. than against other nisin sensitive genera (Rogers and Montville, 1991). Pediocins are also effective, but these bacteriocins have broad activity spectra and could inhibit starters or ripening flora.

Steptococcus thermophilus Adria 91L580 has been isolated from raw milk cheese during a screening of bacteria with inhibitory activity against $C$. tyrobutyricum (Boutrou et al., 1995).

One aim of this work was to characterize the inhibitory compound(s) to see whether this strain produces a bacteriocin and, in this case, to find out whether it differs from the other thermophilins. The other aim was to evaluate the potential of using this strain to inhibit C. tyrobutyricum in hard cheese process. The effect on inhibitory compound production of different conditions of culture close to hard cheese process has been tested: thermic cycle, milk medium, and coculture with a thermophilic Lactobacillus have been evaluated. Small curds made with producing and nonproducing strains of 
S. thermophilus inoculated with spores of Clostridium tyrobutyricum were also tested.

\section{MATERIALS AND METHODS}

\section{Strains and Culture Conditions}

Streptococcus thermophilus ADRIA 91 L580 (noted as ST580) has been isolated from raw milk in ADRIA laboratory. It was first identified as $S$. thermophilus by classical identification gallery (API System, Biomerieux) then by hybridization with the $S$. thermophilus DNA-specific probe pNST22 and has also been proved to be close to a reference strain suitable for hard cheese making by pulsed-field gel electrophoresis (Boutrou et al., 1995). Streptococcus thermophilus NG40Z, which is used as a sensitive strain for main tests, came from the ITG collection (Institut Français du Fromage, Bourg en Bresse, France). The Lactobacillus delbrueckii subsp. lactis strain is a commercial starter obtained from Chr. Hansen (Arpajon, France). All strains were maintained as frozen stocks at $-80^{\circ} \mathrm{C}$ in the presence of $15 \%$ glycerol. Working cultures were maintained on agar slants at $+4^{\circ} \mathrm{C}$ and subcultured twice in liquid media before use. Media were M17 (Merck, Darmstadt, Germany) and MRS (Merck) for S. thermophilus and Lactobacillus, respectively. When bacteriocin production was studied, a reconstituted M17 medium called M17r with $10 \mathrm{~g} \mathrm{~L}^{-1}$ of lactose added after autoclaving was used because little to no production was observed on commercial M17.

Other strains used for inhibitory spectrum determination are listed in Table 1 (origin, media, and culture conditions).

\section{Experimental Design}

Bacteriocin production by $S$. thermophilus 580 was first studied in M17r broth at $41^{\circ} \mathrm{C}$ (optimal temperature). In this case, $S$. thermophilus 580 was inoculated with $4.10^{7} \mathrm{ml}^{-1}$ cells from an exponential phase culture. After mixing, the medium was divided into aliquots of $5 \mathrm{ml}$ in sterile tubes and incubated at the selected temperature. Each tube was used as a sample and removed at different times for titration of bacteriocin and cells number estimation by optical density measurement at $650 \mathrm{~nm}$ (spectrophotometer Milton Roy). A second experiment was made with the same medium and inoculation level but with a temperature gradient (Figure 1) reproducing the first $24 \mathrm{~h}$ of a hard cheese technology (Chamba and Prost, 1989). This was achieved in a $1.5 \mathrm{~L}$ of fermentor controlled with a numeric regulation unit (Set 2M and MRU, Inceltech New Brunswick Scientific, Toulouse, France).

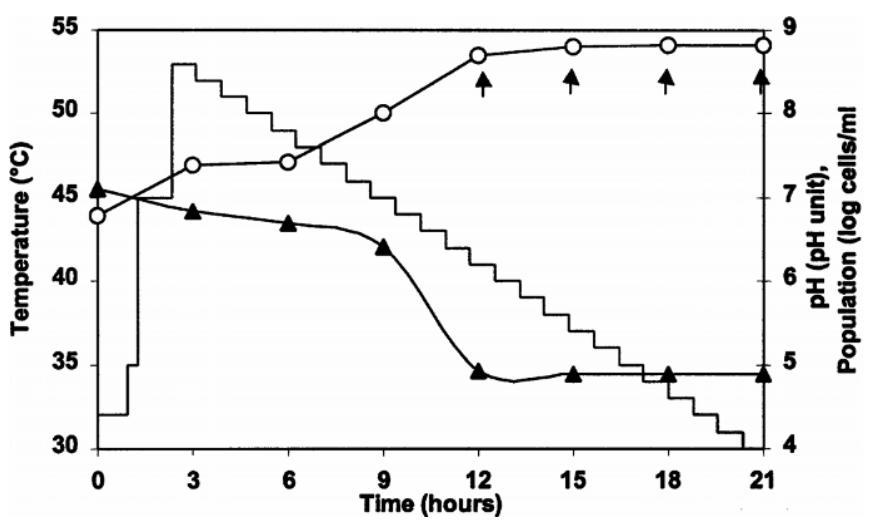

Figure 1. Growth $(\bigcirc)$, acidification (pH:A), and bacteriocin production of ST580 in M17r medium during the application of hard cheese process thermic gradient. The temperature programmation is indicated as a line. Samples in which bacteriocin was detected are indicated by an arrow under the population symbol (No quantification of the inhibitory activity was done.)

Then the synthesis of the bacteriocin was tested in milk using sterile reconstituted ( $10 \% \mathrm{wt} / \mathrm{vol})$ skim milk (RSM) (Difco, Detroit, MI) with added $0.15 \mathrm{ml} \mathrm{L}^{-1}$ standard liquid rennet (Chymosin [EC 3.4.23.4] >500 mg $\mathrm{ml}^{-1}$, Cooperation Pharmaceutique Française, Melun, France). The cultures in RSM were performed at a constant temperature of $37^{\circ} \mathrm{C}$. Either S. thermophilus alone or S. thermophilus and Lactobacillus delbrueckii subsp. lactis were inoculated at a total level of $2.10^{7}$ $\mathrm{ml}^{-1}$ cells from an exponential phase culture. When these two strains were associated, the inoculum was of $1.10^{7} \mathrm{cfu} \mathrm{ml}^{-1}$ of each. After mixing, the milk was treated as the M17r medium and divided in 5-ml aliquots. Chymosin was only added here to perform the bacteriocin assay as described by Torri Tarelli et al. (1994) and, in this experiment, no separation of the coagulated material was made. Enumeration was performed on prepoured agar media using spiral-plating method (D model, AES, Combourg, France). The selective enumeration was obtained on M17 agar, incubated 24 to $48 \mathrm{~h}$ aerobically at $37^{\circ} \mathrm{C}$ for $S$. thermophilus and on acidified MRS agar ( $\mathrm{pH} 5.4$ ), incubated 48 to $72 \mathrm{~h}$ anaerobically at $37^{\circ} \mathrm{C}$ for Lactobacillus. The $\mathrm{pH}$ was measured using a $\mathrm{pH}$ meter (Tacussel electronic).

Each type of culture was repeated at least one time. The growth of the strains was described using the modified Gompertz equation (Zwietering et al., 1990): decimal growth rate $\left(\mu_{10}, h^{-1}\right)$, lag phase $(\lambda, h)$, and asymptotic value of maximal increase in population (A) were determined by fitting the growth curve with the model.

Small-scale curds were also made with $S$. thermophilus and Clostridium tyrobutyricum. Chymosin-treated milk was inoculated with $3.10^{7} \mathrm{cfu} / \mathrm{ml}$ of either ST 580 
or a nonbacteriocin producing strain of $S$. thermophilus: NG40Z. After mixing, the RSM was divided into aliquots of $10 \mathrm{ml}$ in small centrifugation tubes and spores of Clostridium tyrobutyricum 608 were added at two levels: $10^{2}$ and $10^{4} / \mathrm{ml}$. A control with no spores was also made. Three tubes were made for each of the six combinations. The same temperature gradient as in the second experiment was then applied to milk, except that after heating the milk at $53^{\circ} \mathrm{C}$ for $40 \mathrm{~min}$, the curd was broken, and the tubes were centrifuged $(20 \mathrm{~min}$, $900 \times g)$ and $8.2 \mathrm{ml}$ of whey was discarded from each tube. The $\mathrm{pH}$ of the curds were 5.2 and 5.6 for bacteriocin producing (ST580) and nonbacteriocin-producing (NG40Z) strains of $S$. thermophilus, respectively. Sterile solid paraffin was added to maintain anaerobiosis and to visualize the production of gas by C. tyrobutyricum. The temperature gradient was achieved. The tubes were kept at $24^{\circ} \mathrm{C}$, which is the temperature of a "hot-ripening" cellar, and observed daily for $20 \mathrm{~d}$.

\section{Assay for Bacteriocin Activity}

Susceptibility testing was performed by a deferred antagonism method as described previously (Thuault et al., 1991). M17r agar plates were inoculated with about 50 cfu of ST580 using the Spiral inoculating system. After $30 \mathrm{~min}$ at room temperature, the agar was overlaid with soft M17 agar (agar $0.7 \mathrm{~g} \mathrm{~L}^{-1}$ ) and incubated at $37^{\circ} \mathrm{C}$ for $24 \mathrm{~h}$. Then a last soft agar layer seeded with $10^{5} \mathrm{cfu} \mathrm{ml}^{-1}$ of the putative sensitive strain was poured (the medium is chosen to support good growth of the strain; Table 1). A final incubation was performed at optimum time temperature combination for this strain. Inhibition areas were examined.

Bacteriocin production by Lactobacillus strain was also tested with the same method on buffered MRS (Dextrose $2 \mathrm{~g} \mathrm{~L}^{-1}$ ) using ST580, NG40Z, and C. tyrobutyricum 608 as sensitive strains.

Bacteriocin activity was measured in neutralized cellfree supernatants (NCFS). For M17r medium, the NCFS were obtained after neutralization to $\mathrm{pH} 6.5$ and filter sterilization (Sartorius, $0.2 \mu \mathrm{m}$ ). For RSM, cellfree supernatants were obtained as described by Torri Tarelli et al. (1994). Samples were mixed in sodium citrate (vol/vol, 1/1) at a final concentration of $0.05 \mathrm{M}$. After $1 \mathrm{~h}$ at $37^{\circ} \mathrm{C}$, the solution was adjusted to $\mathrm{pH} 6.5$ and centrifuged $(2 \mathrm{~min}, 2700 \times \mathrm{g})$. After filter sterilization, (Sartorius, $0.2 \mu \mathrm{m}$ ), the NCFS was assayed for bacteriocin activity. No effect of the treatment with sodium citrate on the amount of bacteriocin has been observed in M17r broth samples.

Bacteriocin activity was estimated by a modified agar well diffusion assay, essentially as described by Parente et al. (1995). Molted M17 agar $\left(48^{\circ} \mathrm{C}\right)$ was first seeded with the indicator strain (S. thermophilus NG40Z) to a final concentration of $10^{5} \mathrm{cfu} \mathrm{ml}^{-1}$. The inoculated medium was rapidly poured into sterile petri dishes and after solidification, dried for at least $30 \mathrm{~min}$ at room temperature. Six to eight wells of uniform diameter $(\mathrm{Dw}=8 \mathrm{~mm}$ ) were bored in an agar dish. Serial twofold dilutions of the NCFS in sterile M17 without sugar were dispensed in wells $(\mathrm{V}=0.06 \mathrm{ml})$. Plates were allowed to stand overnight at $10^{\circ} \mathrm{C}$ for bacteriocin diffusion, then were incubated at $37^{\circ} \mathrm{C}$ for $24 \mathrm{~h}$. The diameters of the inhibition zones (Di) were measured. Results were read either as a critical dilution assay (the titer of bacteriocin, in arbitrary units [AU] $\mathrm{ml}^{-1}$, of the sample was calculated as LDF/V, where LDF is the dilution factor of the last well giving an inhibition zone larger than $10 \mathrm{~mm}$ ) or as a quantitative assay. For the latter, an average slope (S) representing the increase of Di-Dw when increasing the amount of bacteriocin has been determined using 35 samples $(S=0.81 \times 0.13)$. The activity of one dilution of the sample (DA) was calculated as follows:

$\mathrm{DA}\left(\mathrm{ml}^{-1}\right)=(1000 / 60) \cdot \mathrm{FD} \cdot 10^{(\mathrm{Di}-\mathrm{Dw} / \mathrm{S})}$, where $\mathrm{FD}$ is the dilution factor.

The activity $\left(\mathrm{AU} \mathrm{ml} \mathrm{m}^{-1}\right.$ ) of the sample was the average of the activities for dilutions, giving an inhibition zone larger than $10 \mathrm{~mm}$.

\section{Sensitivity to Enzymes and Heat Treatments}

The NCFS were treated with catalase (EC 1.11.1.6), lipase (EC 3.1.1.3), $\alpha$-amylase (EC 3.2.1.1), $\alpha$-chymotrypsin (EC 3.4.21.1), papain (EC 3.4.22.2), ficin (EC 3.4.22.3), proteinase K (EC 3.4.21.64), (all from Sigma, St. Louis, MO) trypsin (EC 3.4.21.4), and pronase E (EC 3.4.24.31) (Boehringer Manheim) at a final concentration of $1 \mathrm{mg} \mathrm{ml}^{-1}$ in sodium phosphate buffer (10 $\mathrm{m} M, \mathrm{pH}$ 7). Rennet was also used at final concentrations of $0.15,0.25$, and $0.40 \mathrm{ml} \mathrm{L}^{-1}$. Samples with and without enzymes were incubated at $37^{\circ} \mathrm{C}$ for $1.5 \mathrm{~h}$. To test heat stability, the supernatant fluid was heated in water at 60 and $100^{\circ} \mathrm{C}$ for 10,30 , and $60 \mathrm{~min}$. Activity of the samples was detected by the critical dilution assay method as described above.

\section{Molecular Weight Determination}

For a preliminary determination of the molecular weight of the bacteriocin produced by ST 580, crude bacteriocin extract was subjected to ultrafiltration by centrifugation through membranes (centrisart, Sartorius) of different threshold: $5,10,20$, and $100 \mathrm{kDa}$. Centrifugations were performed at $900 \times g, 4^{\circ} \mathrm{C}$ for 58 , 16,16 , and $7 \mathrm{~min}$, respectively, to obtain half of the initial volume in the filtrate. Activity in both retentates and filtrates was determined as described above. 
Table 1. Inhibition spectrum of activity of the bacteriocin from Streptococcus thermophilus 580.,2

\begin{tabular}{|c|c|c|c|}
\hline Indicator strain & Origin & $\begin{array}{l}\text { Medium, } \\
\text { temperature }\end{array}$ & $\begin{array}{l}\text { Average } \\
\mathrm{IAD}^{3}(\mathrm{~mm})\end{array}$ \\
\hline Streptococcus thermophilus NG40Z & ITG & $\mathrm{M} 17,41^{\circ} \mathrm{C}$ & $14-15$ \\
\hline $\begin{array}{l}\text { Lactobacillus delbrueckii subsp. lactis } \\
\text { (starter) }\end{array}$ & Chr Hansen & $\mathrm{MRS}, 37^{\circ} \mathrm{C}$ & 0 \\
\hline $\begin{array}{l}\text { Lactobacillus delbrueckii subsp. lactis } \\
\text { B-735, B-1240, B1844 }\end{array}$ & NRRL & $\mathrm{MRS}, 37^{\circ} \mathrm{C}$ & 0 \\
\hline $\begin{array}{l}\text { Lactobacillus delbrueckii subsp. } \\
\text { bulgaricus L18 }\end{array}$ & INA-PG & $\mathrm{MRS}, 42^{\circ} \mathrm{C}$ & 0 \\
\hline Lactobacillus helveticus H7 (starter) & STANDA & $\mathrm{MRS}, 37^{\circ} \mathrm{C}$ & 0 \\
\hline Lactobacillus helveticus & NRRL & $\mathrm{MRS}, 37^{\circ} \mathrm{C}$ & 0 \\
\hline \multicolumn{4}{|l|}{ B-1842, B-1929, B-1942, B- 4526} \\
\hline Lactobacillus acidophilus (starter) & Chr Hansen & $\mathrm{MRS}, 37^{\circ} \mathrm{C}$ & 0 \\
\hline Enterococcus faecium & IUTQ & $\mathrm{M} 17,37^{\circ} \mathrm{C}$ & 23 \\
\hline Enterococcus faecalis 29912 & ATCC & $\mathrm{M} 17,37^{\circ} \mathrm{C}$ & $6-8$ \\
\hline Micrococcus luteus & IUTQ & $\mathrm{BHI}, 30^{\circ} \mathrm{C}$ & 0 \\
\hline Brochothrix thermosphacta 6911 & IPP & $\mathrm{BHI}, 25^{\circ} \mathrm{C}$ & $16-18$ \\
\hline Listeria innocua 33090 & ATCC & $\mathrm{BHI}, 30^{\circ} \mathrm{C}$ & $1-2$ \\
\hline Listeria monocytogenes 7838 & IPP & $\mathrm{BHI}, 30^{\circ} \mathrm{C}$ & 0 \\
\hline Staphylococcus aureus 156 & LCHA & $\mathrm{BHI}, 37^{\circ} \mathrm{C}$ & 0 \\
\hline Bacillus cereus 1101 & IPP & $\mathrm{RCM}, 30^{\circ} \mathrm{C}$ & $8-10$ \\
\hline Clostridium sporogenes 60531 & IPP & $\mathrm{RCM}, 37^{\circ} \mathrm{C}$ & $15-20$ \\
\hline Clostridium butyricum 5291 & INRA-CNRZ & $\mathrm{RCM}, 37^{\circ} \mathrm{C}$ & $15-20$ \\
\hline Clostridium tyrobutyricum 6081 & INRA-CNRZ & $\mathrm{RCM}, 37^{\circ} \mathrm{C}$ & $11-12$ \\
\hline Escherichia coli 54127 & IPP & $\mathrm{BHI}, 30^{\circ} \mathrm{C}$ & 0 \\
\hline Pseudomonas putida J7 & ADIV & $\mathrm{BHI}, 30^{\circ} \mathrm{C}$ & 0 \\
\hline
\end{tabular}

${ }^{1}$ Susceptibility testing was performed by a deferred antagonism method as described previously (Thuault et al., 1991).

${ }^{2}$ Orgin abbreviations and location: ITG Institut français du fromage, Bourg en Bresse, Chr Hansen, Arpajon, Fr. NRRL Agricultural Research Service Culture Collection, Peoria, Illinois, USA, INA-PG Institut National d'Agronomie, Paris Grignon, Fr. STANDA industrie, Caen, Fr. IUTQ Institut Universitaire de Technologie, Département de Génie Biologique, Quimper, Fr. ATCC American Type Culture Collection, Rockville, MD, USA. IPP Institut Pasteur Paris, Fr. LCHA Laboratoire Central d'Hygiène Alimentaire, Fr. INRA CNRZ Institut National de la Recherche Agronomique, Jouy en Josas, Fr. ADIV Association pour le développement de I'Insititut de la Viande, Clermont Ferrand, Fr. Culture media: M17 (Terzaghi and Sandine, 1975) Merck 15029. MRS (de Man et al., 1960) Merck 10661. BHI Brain Heart Infusion, Oxoid CM 225. RCM Reinforced Clostridial Medium, Merck 5411.

${ }^{3} \mathrm{IAD}=$ inhibition area diameter.

\section{RESULTS}

\section{Partial Characterization}

Effects of heat and enzymes treatments. The effect of heat and some enzymes on crude extract was investigated (data not shown). The inhibitory substance was completely inactivated by most of the proteases: trypsin, ficin, pronase E, and papain. The activity was reduced to $25 \%$ of the control with proteinase $\mathrm{K}$. No modification of activity was observed when bacteriocin was treated with catalase or lipase. Buffers and enzymes solutions alone had no effect on the indicator strain. This suggests that the antimicrobial substance produced by ST580 could be a proteinacous inhibitory substance, that is, a bacteriocin (Tagg et al., 1976).

An inactivation with $\alpha$-amylase was also observed. Rennet has no effect: Activity was the same as the control for 0.15 and $0.25 \mathrm{ml} \mathrm{L}^{-1}$.

Bacteriocin produced by ST580 was not stable under heat treatments; the inhibitory activity was maintained only up to $10 \mathrm{~min}$ at $60^{\circ} \mathrm{C}$. At the same temperature, half activity was lost after $30 \mathrm{~min}$, and the whole activity by heating for $1 \mathrm{~h}$.

Molecular weight determination. During preliminary ultrafiltration studies of crude bacteriocin, no activity was detected in any filtrate; $27,47,41$, and $27 \%$ of the initial activity were found in the retentate for membranes of cut-off $5,10,20$, and $100 \mathrm{kDa}$, respectively. These results suggest that the bacteriocin forms aggregates of more than $100 \mathrm{kDa}$. More than $50 \%$ of the activity was lost during the filtration treatment.

Inhibition spectrum of activity. For the antimicrobial spectrum of activity, a three-layers method was used. Various gram-positive bacteria of food interest and two gram-negative bacteria were tested. Table 1 indicates that the bacteriocin of ST 580 has a rather narrow spectrum, being active mainly against other thermophilic Streptococci, Brochothrix, and sporulated gram-positive rods (Clostridium sp., Bacillus cereus). Inhibition of Enterococcus and Listeria was very lim- 


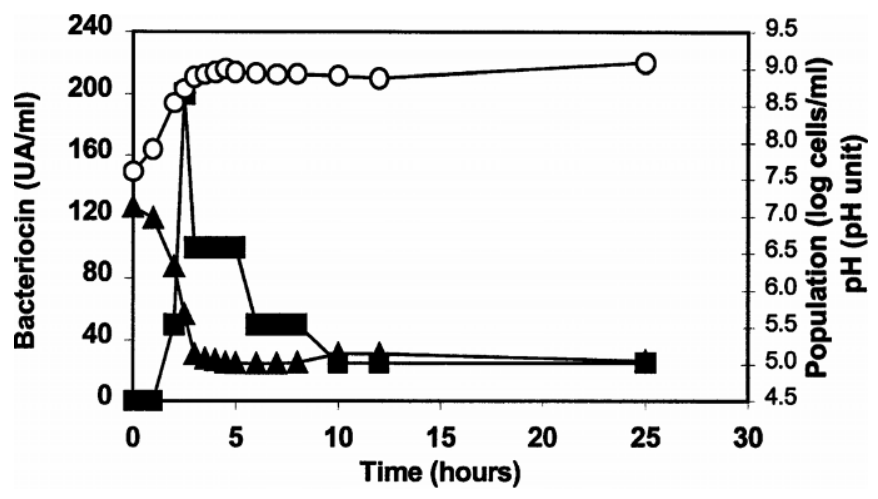

Figure 2. Growth $(\bigcirc)$, acidification ( $\mathrm{pH}: \mathbf{\Delta})$, and bacteriocin production (obtained by the critical dilution assay: $\mathbf{0}$ ) by ST580 in M17r medium at $41^{\circ} \mathrm{C}$. Points represent data from a single trial. Other trials had similar patterns for growth, acidification and bacteriocin production.

ited, and the other bacteria tested were not inhibited at all.

\section{Bacteriocin Production}

Production of bacteriocin in M17 medium. The production in $\mathrm{M} 17 \mathrm{r}$ broth at $41^{\circ} \mathrm{C}$ was dependent on the phase of bacterial growth (Figure 2). ST 580 started to produce bacteriocin during the exponential growth phase and the concentration reached a maximum at the end of this phase; the concentration then dramatically decreased.

In a thermic cycle on M17r medium, both bacterial growth and bacteriocin production occurred after the heating period (Figure 1).

Growth and production of bacteriocin in milk in pure and cocultures. The parameters describing the growth of ST580 and the initial and maximal populations in each type of culture are reported in Table 2.
The asymptotic increase of the population (A) is the only significantly different parameter between pure and cocultures. However, because of the different size in the inoculum, the maximum populations of ST 580 and even of the total bacteria are not significantly different.

No bacteriocin production or inhibitory activity of $L$. delbrueckii subsp. lactis has been observed against either $S$. thermophilus or C. tyrobutyricum strains. The inhibitory activity observed in cocultures is the result of the bacteriocin production by ST 850 only.

Bacteriocin production in milk shows the same phases as in M17r medium (Figure 3): the maximum is reached at the end of the exponential growth phase (data not shown). For the maximum reached, although the standard deviation are important, the mean of the coculture is significantly different from the mean of the pure cultures indicating that coculture could enhance bacteriocin production. But the decrease in activity during the stationary phase leads to the same amount at the end of both cultures $(24 \mathrm{~h})$.

Inhibition of Clostridium spores in curds. During the $20 \mathrm{~d}$ of ripening, all control tubes without spores of Clostridium tyrobutyricum remained unchanged (no gas produced). For the curds made with the nonbacteriocin-producing strain $\mathrm{NG} 40 \mathrm{Z}$, gas production could be visualized after $8 \mathrm{~d}$ for the $10^{4}$ spores $/ \mathrm{ml}$ level and after $14 \mathrm{~d}$ for the $10^{2}$ spores $/ \mathrm{ml}$ level, whereas the curds made with the bacteriocin producing strain ST580 showed no gas production for up to $20 \mathrm{~d}$.

\section{DISCUSSION}

This work describes the partial characterization of a bacteriocin produced by $S$. thermophilus 580, isolated from raw milk cheese.

The results show that the inhibitory activity of this strain is due to a heat labile peptide. This heat instabil-

Table 2. Growth parameters of Streptococcus thermophilus 580 in pure culture and in coculture with Lactobacillus delbrueckii subsp. lactis in milk at $37^{\circ} \mathrm{C} .^{1}$

\begin{tabular}{|c|c|c|c|c|c|c|c|}
\hline \multirow[b]{2}{*}{ Culture } & \multicolumn{5}{|c|}{ Streptococcus thermophilus } & \multicolumn{2}{|c|}{ Total population } \\
\hline & $\lambda$ & $\mu 10$ & $\mathrm{~A}$ & $\begin{array}{l}\text { Log } \\
\text { No }\end{array}$ & $\begin{array}{l}\text { Log } \\
\text { Nmax }\end{array}$ & Log No & $\begin{array}{l}\log \\
\text { Nmax }\end{array}$ \\
\hline Pure culture & $\begin{array}{l}1.20 \pm \\
0.23\end{array}$ & $\begin{array}{l}0.91 \pm \\
0.16\end{array}$ & $\begin{array}{l}1.37 \pm \\
0.05\end{array}$ & $\begin{array}{l}7.22 \pm \\
0.11\end{array}$ & $\begin{array}{l}8.59 \pm \\
0.16\end{array}$ & & \\
\hline $\begin{array}{l}\text { Coculture with } \\
\text { Lactobacillus }\end{array}$ & $\begin{array}{l}0.93 \pm \\
0.02\end{array}$ & $\begin{array}{l}0.99 \pm \\
0.08\end{array}$ & $\begin{array}{l}2.01 \pm \\
0.01\end{array}$ & $\begin{array}{l}6.79 \pm \\
0.08\end{array}$ & $\begin{array}{l}8.81 \pm \\
0.07\end{array}$ & $\begin{array}{l}7.17 \pm \\
0.02\end{array}$ & $\begin{array}{l}9.01 \pm \\
0.11\end{array}$ \\
\hline
\end{tabular}

${ }^{1}$ Parameters $\lambda, \mu 10$ and A were determinated by fitting the growth curves with the Gompertz equation (modified by Zweitering et al., 1990). The residual sums of squares calculated with observed and predicted values were less than $0.120 . \lambda$ is the lag phase (h), $\mu 10$ is the maximum decimal growth rate (h-1) and A is the maximum increase of population (asymptotic value of $\log \mathrm{N} / \mathrm{No}$ went $t$ tend to + ). Log No is the logarithm of the initial population and log Nmax is the asymptotic maximal population as calculated with $\log$ No and A. Values are the means and standard deviations of two separate experiments. 


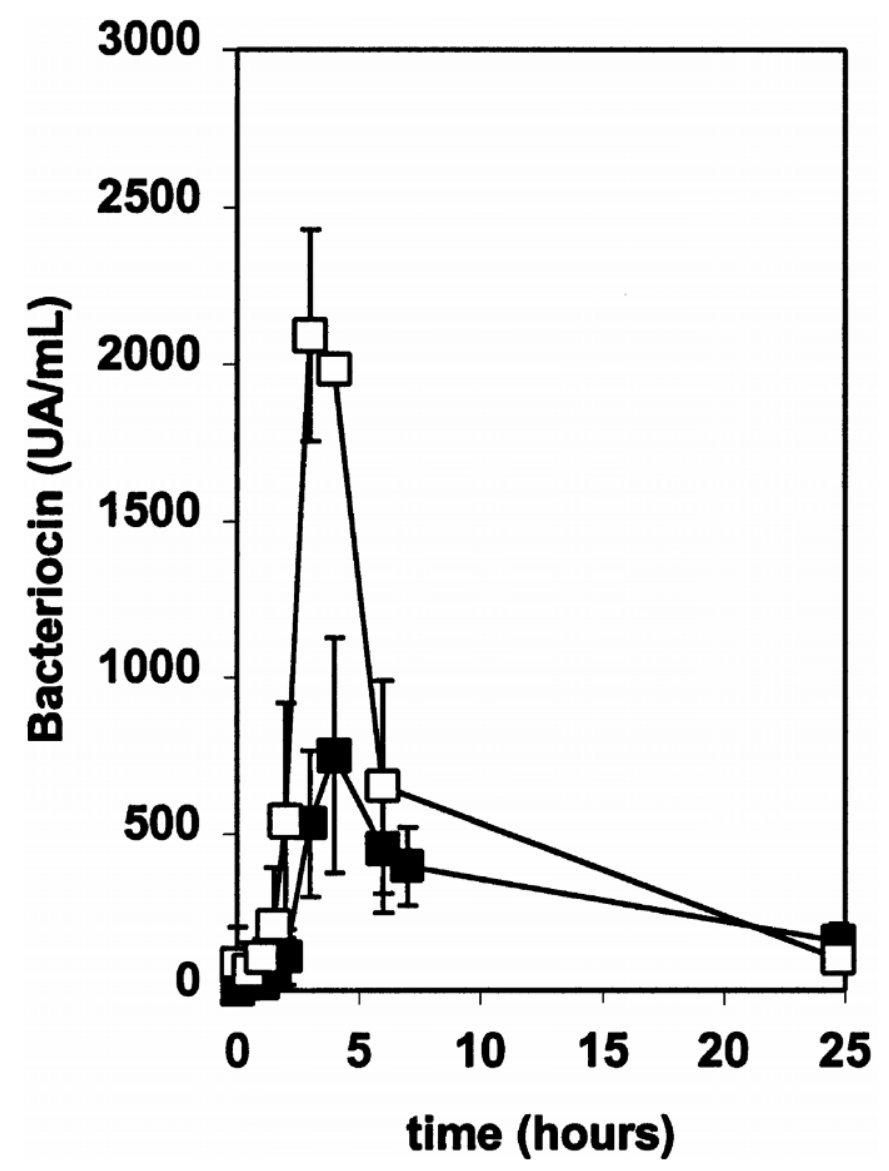

Figure 3. Bacteriocin production by ST580 in pure (ם) and mixed ( $\square$ ) culture with Lactobacillus delbrueckii subsp. lactis in milk at $37^{\circ} \mathrm{C}$. Bacteriocin determined with the quantitative method (see text). Each point and error bar represents the mean and standard deviation of two separate experiments.

ity has not been shown for other thermophilins, and all the already described ones do resist to a heat treatment of at least $45 \mathrm{~min}$ at $100^{\circ} \mathrm{C}$ (Villani et al., 1995; Ward and Somkuti, 1995; Marciset et al., 1997; Aktypis et al., 1998; Ivanova et al., 1998). But some bacteriocins, especially those from the thermophilic, species: Lactobacillus helveticus are thermolabile and, for instance, helveticin V18-29 is inactivated after $30 \mathrm{~min}$ at $50^{\circ} \mathrm{C}$ (Vaughan et al., 1992). Although this sensitivity could be a disadvantage for using this strain in hard cheese making, we showed that when the strain is put through a cycle of temperature similar to cheese processing both the growth of the strain and the bacteriocin production are delayed and occurred when the temperature has decreased under about $48^{\circ} \mathrm{C}$.

The bacteriocin from $S$. thermophilus 580 is inactivated by most proteases, but it is also inactivated by $\alpha$-amylase. Similar observations were made for thermophilin $\mathrm{A}$ and $\mathrm{T}$ and for other bacteriocins from lactic acid bacteria. It indicates a putative presence of glycosidic moiety, which may be required for activity (Ward and Somkuti, 1995; Aktypis et al., 1998).

The molecular weight of the studied bacteriocin has not been determined yet, but the ultrafiltration experiments suggested a tendency to aggregate. Thermophilin $\mathrm{T}$ has the same property, and the purified material has a molecular mass of about $2.4 \mathrm{kDa}$ (Aktypis et al., 1998). However, its low resistance to heat treatment suggests a large size bacteriocin.

An interesting feature of this bacteriocin is its spectrum of activity, which is close to the one of Thermophilin $\mathrm{T}$ but with no activity against the thermophilic lactobacilli (11 strains tested). That circumstance means that the productive strain ST 580 could be used in a thermophilic starter with other strains of Lactobacillus for hard cheese making (or possibly yogurt) without causing inhibition of the latter. This is one of the reasons why the production in coculture was tested.

Although some more experiments (and more precisely purification and determination of the sequences of these bacteriocins) are needed, the bacteriocin produced by ST580 seems to be distinct from those already described.

As for many bacteriocins of lactic acid bacteria, the production is related to the growth phase, and highest titers were obtained at the end of the exponential phase. Further incubation results in a decrease in the bacteriocin activity during the stationary phase that could be attributed either to a proteolytic degradation, to a $\mathrm{pH}$ mediated inactivation or to adsorption to the producer cells (Villani et al., 1995).

Coculture of ST580 and L. delbrueckii subsp. lactis results in an enhanced bacteriocin production. The maximum level reached is about twice the pure culture one. To our knowledge, a synergistic action of this type has not been reported yet. Few experiments have been done on cultivation of a bacteriocin producing strain with one resistant strain of an other genera. When lacticin 481 producing Lactococcus lactis CNRZ 481 is associated with a sensitive strain of Lactococcus, no effect on bacteriocin production was found (Piard et al., 1990). A bacteriocin-producing strain of Enterococcus faecalis has been cocultured with a mesophilic homofermentative commercial starter. The level of bacteriocin during all the duration of Manchego cheese making is less (Garcia et al., 1997). The same observations were made either for a Lactococcus lactis nisin producer associated with a DL mesophilic commercial starter during Manchego cheese ripening: about $30 \%$ less bacteriocin was found (Rodriguez et al., 1998) or with an Enterococcus faecium strain co-cultured with two strains of a thermophilic type starter in milk. Production of bacteriocin was about half of the level observed in pure culture 
(Giraffa et al., 1995). In this last case, however, inhibition of Listeria monocytogenes was enhanced by acid $\mathrm{pH}$ in coculture. The authors of these studies emphasize the competition for nutriments that could limit growth and or bacteriocin production. However, they have not precisely quantified the parameters of the strains growth.

Cooperation between $S$. thermophilus and $L$. delbrueckii subsp. bulgaricus has been studied in the past and the stimulation of the streptococcus growth is mainly the result of a complementarity between proteolytic systems (Juillard et al., 1987). Although there is less information about $L$. delbrueckii subsp. lactis, it is possible that the higher final population in coculture is a result of such a stimulation because this lactobacillus also has some proteolytic activity (Sasaki et al., 1995).

As more generations of $S$. thermophilus happened in coculture, it could have an effect on the bacteriocin produced. To evaluate this effect, we have tested the growth and bacteriocin production in $\mathrm{M} 17 \mathrm{r}$ with four different inocula from $4.10^{6}$ to $8.10^{7} \mathrm{cfu} \mathrm{ml}^{-1}$. Bacteriocin production was always maximum at the end of the exponential growth phase and was delayed when the inoculum density was smaller, but we observed no effect on the maximum amount of bacteriocin produced, which was in all cases between 1900 and $2200 \mathrm{AU} \mathrm{ml}^{-1}$.

In curds made with bacteriocin producing or nonbacteriocin-producing strains of $S$. thermophilus, the former seems to be very interesting for Clostridium inhibition, but the amount of bacteriocin has not be evaluated because the method of Torri Tarelli et al. (1994) could not be applied to curd. It is also important to note that the $\mathrm{pH}$ were not exactly the same in the two types of curd because the strain NG40Z is a little slower than ST580 for milk acidification in the cheese process. This could participate to Clostridium inhibition (Huchet et al., 1995).

We can conclude that $S$. thermophilus 580 produces a new bacteriocin that seems to have good potential for use in cheese making to prevent spoilage by $C$. tyrobutyricum.

\section{REFERENCES}

Abee, T., L. Krockel, and C. Hill. 1995. Bacteriocins: Modes of actions and potentials in food preservation and control food poisoning. Int. J. Food Microbiol. 28:169-185.

Aktypis, A., G. Kalantzopoulos, J. H. J. Huis in't Veld, and B. Ten brink. 1998. Purification and characterization of thermophilin T, a novel bacteriocin produced by Streptococcus thermophilus ACADC 0040. J. Appl. Microbiol. 84:568-576.

Boutrou, R., D. Thuault, and C. M. Bourgeois. 1995. Identification and characterization of Streptococcus thermophilus strains by pulsed-field gel electrophoresis. J. Appl. Bacteriol. 79:454-458.
Chamba, J. F., and F. Prost. 1989. Mesure de l'activité acidifiante des bactéries lactiques thermophiles utilisées pour les fabrications des fromages à pâte cuite. Lait 69:417-431.

Garcia, E., M. De Paz, P. Gaya, M. Medina, and M. Nuñez. 1997. Inhibition of Listeria innocua in Manchego cheese by bacteriocinproducing Enterococcus faecalis INIA 4. Milchwissenschaft 52:667-670.

Giraffa, G., D. Carminati, and G. Torri Tarelli. 1995. Inhibition of Listeria innocua in milk by bacteriocin-producing Enterococcus faecium 7C5. J. Food Prot. 58:621-623.

Huchet, V., D. Thuault, and C.M. Bourgeois. 1995. Modélisation des effets du $\mathrm{pH}$, de l'acide lactique, du glycérol et du $\mathrm{NaCl}$ sur la croissance des cellules végétatives de Clostridium tyrobutyricum en milieu de culture. Lait 75:585-593.

Ivanova, I., V. Miteva, Ts. Stefanova, A. Pantev, I. Budakov, S. Danova, P. Moncheva, N. Kotova, X. Dousset, and P. Boyaval. 1998. Characterization of a bacteriocin produced by Streptococcus thermophilus 81. Int. J. Food Microbiol. 42:147-158.

Juillard, V., H. E. Spinnler, M. J. Desmazeaud, and C.Y. Boquien. 1987. Phénomènes de coopération et d'inhibition entre les bactéries lactiques utilisées en industrie laitière. Lait 67:149-172.

de Man, J. C., M. Rogosa, and M. E. Sharpe. 1960. A medium for the cultivation of Lactobacilli. J. Appl. Bacteriol. 23:130-135.

Marciset, G., M. C. Jeronimus-Stratingh, B. Mollet, and B. Poolman. 1997. Thermophilin 13, a nontypical antilisterial poration complex bacteriocin, that functions without a receptor. J. Biol. Chem. 272:14277-14284.

Parente, E., C. Brienza, M. Moles, and A. Ricciardi. 1995. A comparison of methods for the measurement of bacteriocin activity. J. Microbiol. Methods 22:95-108.

Piard, J. C., F. Delorme, G. Giraffa, J. Commissaire, and M. Desmazeaud. 1990. Evidence for a bacteriocin produced by Lactococcus lactis CNRZ 481. Neth. Milk Dairy. 44:143-158.

Rodriguez, E., P. Gaya, M. Nuñez, and M. Medina. 1998. Inhibitory activity of a nisin-producing starter culture on Listeria innocua in raw ewes milk Manchego cheese. Int. J. Food Microbiol. 39:129-132.

Rogers, A. M., and T. J. Montville. 1991. Improved agar diffusion assay for nisin quantitation. Food Biotechnol. 5:161-168.

Ross, R. P., M. Galvin, O. Mc Auliffe, S. M. Morgan, M. P. Ryan, D. P. Twomey, W. J. Meaney, and C. Hill. 1999. Developing applications for lactococcal bacteriocins. Antonie Van Leeuwenhoek 76:337-346.

Sasaki, M., B. W. Bosman, and P. S. T. Ta. 1995. Comparison of proteolytic activities in various lactobacilli. J. Dairy Res. 62:601-610.

Tagg, J. R., A. S. Dajani, and L.W. Wannamaker. 1976. Bacteriocins of gram-positive bacteria. Bacteriol. Rev. 40:722-756.

Terzaghi, B. E., and W. E. Sandine. 1975. Improved medium for lactic streptococci and their bacteriophages. Appl. Microbiol. 29:807813.

Thuault, D., E. Béliard, J. Le Guern, and C. M. Bourgeois. 1991. Inhibition of Clostridium tyrobutyricum by bacteriocin-like substances produced by lactic acid bacteria. J. Dairy Sci. 74:11451150

Torri Tarelli, G., D. Carminati, and G. Giraffa. 1994. Production of bacteriocins active against Listeria monocytogenes and Listeria innocua from dairy enterococci. Food Microbiol. 11:243-252.

Vaughan, E. E., C. Daly, and G. F. Fitzgerald. 1992. Identification and characterization of helveticin V-1829, a bacteriocin produced by Lactobacillus helveticus 1829. J. Appl. Bacteriol. 73:299-308.

Villani, F., O. Pepe, G. Mauriello, G. Salzano, G. Moschetti, and S. Coppola. 1995. Antilisterial activity of thermophilin 347, a bacteriocin produced by Streptococcus thermophilus. Int. Food Microbiol. 25:179-190.

Ward, D. J., and G. A. Somkuti. 1995. Characterization of a bacteriocin produced by Streptococcus thermophilus ST 134. Appl. Microbiol. Biotechnol. 43:330-335.

Zwietering, M. H., I. Jongenburger, F. M. Rombouts, K. Van't Riet. 1990. Modelling of the bacterial growth curve. Appl. Environ. Microbiol. 56:1875-1881. 